\title{
EFFECT OF SOCIO-ECONOMIC CHARACTERISTICS ON THE PERCEPTION OF CLIMATE CHANGE AMONG RURAL RICE FARMERS IN ANAMBRA STATE, NIGERIA
}

\author{
ONYINYECHUKWU HOPE ONUBOGU \\ Department of Agricultural Economics and Extension, Chukwuemeka Odumegwu Ojukwu \\ University, Igbariam. Anambra State. \\ (Correspondence: +2347060764876; onyibim@yahoo.com)
}

\begin{abstract}
This paper ascertained the level of awareness of climate change among rural rice farmers in Anambra Agricultural zone of Anambra state, determined the effect of socio-economic characteristics of the farmers on their perception of climate change, and identified the coping strategies adopted by these farmers to mitigate the impact of climate change. A multistage sampling technique was used to select a total of 120 rice farmers in rice producing areas of Anambra Agricultural zone. Descriptive statistics and Regression analysis were used for the analysis. Results showed that 52\% of the farmers were highly aware of the concept of climate change while 38\% were slightly aware. These rice farmers' perceptions of climate change included high intensity of sun, variation in rainfall duration, change in weather, and poor yield of crops. Number of years in school, Farming experience, sex, number of visits by extension agents and mode of farming were identified as the socioeconomic characteristics affecting farmers' perception of the concept of climate change. The coping strategies adopted by these farmers included adjustment of planting calendar, mixed cropping, close monitoring of weather, improved managerial skills and usage of improved varieties. The study recommended that the extension agents should enlighten the farmers, through an on-farm education, on climate change and its coping strategies, and also, the use of plant varieties that can withstand changes in the climate should be promoted.
\end{abstract}

Key words: Climate change, Awareness, Perception, Socio-economic, Coping strategies 


\section{Introduction}

Climate is generally conceived as the expected weather conditions for specific geographical location. Climate Change refers to any change in the state of the climate over time, whether due to natural variability or as a result of human activity (Ayoola et al. 2011). It may also be referred to as any significant change in measures of climate (such as temperature, precipitation, or wind) lasting for an extended period (decades or longer), and further defined as any sustained alteration in the average daily weather pattern resulting from natural courses of events or human activity (Nzeadibe et al. 2011; Intergovernmental Panel on Climate Change (IPCC), 2014).Climate change has been identified as a global environmental threat which has the potential of affecting all natural and human resources, particularly the agricultural sector, therefore awareness and coping measures are required to reduce the climate vulnerabilities (Falaki et al. 2013; Enimu and Onome, 2018). Nwajiuba and Onyeneke, (2010) identified climate change as one of the most crucial factors that negatively affect sustainable agricultural production and the scope for reducing poverty in Nigeria, and warned that any change in climate is bound to impact on the agricultural sector in particular and other socio-economic activities in general. These impacts could be in terms of effects on crop growth, availability of soil water, health and availability of farm labour, soil fertility, soil erosion, incidents of pests and diseases, and sea level rise (Nwajiuba and Onyeneke, 2010; Nzeadibe et al., 2011; Nwaiwu et al. 2013). Ayoola et al. (2011) affirmed that climate change affects crop production by causing - uncertainties and variation in the pattern of rainfall, floods and devastated farmlands, migration of pests and diseases, and high temperatures which smother crops- and these lead to decline in harvests per annum. The place of this natural phenomenon in sustainable agriculture is of great concern in developing countries especially Nigeria because Agriculture in Nigeria is entirely dependent on climate (Falaki, et al. 2013; Suleiman, 2014; Enimu and Onome, 2018).

Crops grown in Nigeria include yam, cassava, rice, cowpea, millet. Rice is an important food item as it forms the main part of the diet of over one third of the world's population. It is among the most valued cereal crops of West African and has become increasingly used as a constituent of animal feed (Naswem, et al. 2016; Onubogu, et al. 2019). Under the Agricultural Transformation Agenda (ATA) rice is one of the focal crops that the Federal Government intends to use to lift rural farmers from poverty. However, rice production is limited by many biotic and abiotic factors which are aggravated when climate change induces variation in climate patterns and this is a major problem that would be encountered because the major problems associated with rice production include drought, flooding, salt stress and extreme temperatures all of which are expected to worsen with climate change (Naswem et al.2016; Onyegbula, 2017). Onyegbula (2017) stated that rice when compared with other crops is very sensitive to drought which can reduce stand establishment, tillering, plant height, spikelet fertility and also delay flowering. Idoma et al. (2017) also identified stunted growth, wilting due to high temperature, high rate of weed growth, incidence of flooding, occurrence of drought, prevalence of pests and diseases, low rainfall, low rice yield, increase in crop life cycle, and premature rice ripening as climate change related constraints of rice production.

Numerous strategies have been suggested as ways of coping with the effects of climate change, but, farmers' perception of climate change is very essential in the choice of the strategy to adopt. Odewumi et al. (2013) had cautioned that perceptions of farmers have the tendency of influencing their coping and adaptation strategies which ultimately determine the 
extent to which climate impacts on agriculture. Hence, it becomes necessary to ascertain the farmers' perception of climate change because the perception of climate change as a hazard will influence farmers' response to it. Thompson and Oparinde (2015) noted that farmers in rural areas of Ondo State did not have full understanding of the concept of climate change .According to Idoma et al.(2017), rice farmers have different perceptions of climate change and their adaptation practices were identified as use of climate tolerant varieties, early planting of rice, mulching of paddy fields, application of organic fertilizers, and other necessary inputs among others. Ayanlade, et al. (2018) assessed the perception of rural farmers on climate change and preferred adaptation strategies among the farmers in some selected farming communities in Nigeria, and realised that the participants were aware of changes in climate, perceived it in various ways and noted that the length of farming experience, income and age are important factors which help to understand the real scenarios.

From the foregoing, the following research questions are important to this study; i) To what extent are rice farmers in the study area aware of climate change vis-à-vis perception? ii) What socioeconomic characteristics influence farmers' perception of climate change in the study area? iii) What coping strategies do rice farmers adopt to mitigate the impact of climate change? Understanding how farmers perceive changes in climate and what factors shape their perception is useful for adaptation research. Hence, this researchexamined the socio economic characteristics of the rural rice farmers in the study area, ascertained therural rice farmers' awareness and perception of climate change, determined the effect of socio economic characteristics of the farmers on their perception of climate change, and finally identified thestrategies adopted by these farmers to mitigate the impact of climate change.

\section{Materials and Methods}

\section{Study area}

This study was conducted in Anambra agricultural zone of Anambra State, Nigeria. Anambra State is situated in the South-East Geopolitical zone of Nigeria.It is bounded by Kogi State in the North and Imo State in the South. It shares boundaries with Enugu State in the East; while its Western borders are covered by River Niger and Delta State. Anambra State occupies an area of 4,865 sq. km (National Bureau of Statistics, NBS, 2013) with a projected population of 5,527,809 in 2016 (NBS 2017). It has twenty one Local Government Areas (LGAs), and Four Agricultural Zones (AZs) which are Awka, Aguata, Onitsha and Anambra Agricultural zones. Anambra state is a state known for commercial activities and farming. The soil types and climate of the state are suitable for the production of different kinds of crops such as yam, cocoyam, oil palm, rice, citrus fruits, maize. The Anambra agricultural zone is known for rice production in the state (Nwalieji and Onwubuya, 2012; Enibe, et al. 2019).

\section{Data collection}

The population of the study consisted of all the rice farmers in the four AZs of Anambra State. Multistage sampling technique was applied in the selection of respondents for the study. The first stage involved purposive selection of Anambra Agricultural zone out of the 4 AZs in the state because of the high activities of rice production in the area. Anambra Agricultural Zone comprises of Oyi, Anambra East, Anambra West and Ayamelum Local Government Areas (LGAs). In the second stage Ayamelum LGA was selected because it is notable for rice production activities in the State (Nwalieji and Onwubuya, 2012). The three most producing rice communities in Ayamelum LGA (Omor, umumbo, and Ifite-Ogwari) were purposively chosen in the third stage. In the final stage, forty rice farmers were randomly selected from each of the towns. This gave a total of one hundred and twenty (120) 
respondents. The data for the study were collected from the farmers with the use of structured questionnaire.

\section{Data analysis}

Descriptive statistics comprising frequency distribution, mean, percentages were used to describe the socio economic characteristics of the farmers, ascertain the level of climate change awareness, and identify the strategies adapted by these farmers to mitigate the impact of climate change.

A 5-point Likert-type scale was used to ascertain farmers' perception of climate variability in the study area. This was measured on a 5-point Likert scale of Strongly Disagreed (SD), Disagreed (D), Undecided (U), Agreed (A), and Strongly Agreed (SA) which attracted scores of $1,2,3,4$ and 5, respectively. These values $(1,2,3,4,5)$ were added to obtain a value of 15 which was further divided by 5 to get a mean score of 3 . Variables with mean scores less than 3 were regarded as not serious perception while variables with mean scores equal to or above 3 were regarded as serious perception of climate change by rice farmers in the study area (Thompson and Oparinde, 2015).

Multiple regression analysis was used to determine the effects of socio-economic characteristics of the farmers on their perception of climate change. The regression model was specified as follows:

$\mathrm{P}=\mathrm{a}+\beta_{1} X_{1}+\beta_{2} X_{2}+\beta_{3} X_{3}+\beta_{4} X_{4}+\beta_{5} X_{5}+\beta_{6} X_{6}+\beta_{7} X_{7}+\beta_{8} X_{8}+\beta_{9} X_{9}+\mu \ldots$ eqn 1 Where:

$\mathrm{P}=$ dependent variable - this is the level of Climate change perception (measured by the number of perception scores of the respondents. This was obtained by adding up the various points which each respondent scored at each perception questionas indicated on the Likert scale).

$\mathrm{a}=$ constant term

$\beta_{1}, \ldots \ldots, \beta_{9}=$ regression coefficients (parameters to be estimated)

$X_{1}=$ age (measured in years)

$X_{2}=\operatorname{sex}($ male $=1$, female $=0)$

$X_{3}=$ education; (measured by the number of years spent in formal education)

$X_{4}=$ Marital status (married $=1$, otherwise $=0$ )

$X_{5}=$ Household size (measured by the number of people living under one roof and eating from the same pot)

$X_{6}=$ membership of farmers' cooperative (measured by the number of years as a member)

$X_{7}=$ Extension contact (measured by number of times visited by extension agents in a year).

$X_{8}=$ Farming experience (measured in yearsin rice production)

$X_{9}=$ Mode of operation(Full time $=1$, Otherwise $\left.=0\right) ; \quad \mu=$ error term

\section{Results and Discussion}

Socio-economic characteristics of the farmers

The results of the socio economic characteristics of the respondents as displayed on Table 1 show that the majority $(43.3 \%)$ of the respondents were between the age range of 41 to 50 years. Farmers whose ages were $30-40$ years, above 60 years and $51-60$ years made up $25.0 \%, 15 \%$ and $10.0 \%$ respectively of the farmers sampled while the remaining $(6.7 \%)$ were less than 30 years. The mean age of the respondents was 45.6 years. This implies that 
majority of the respondents were within the active and productive ages, which connotes a promising future for rice farming in the area.

Table 1: Distribution of Respondents according to their Socio-economic Characteristics Age (Years)

\section{Personal Characteristics}

Frequency Percentage $(\%)$ Mean

Below 30

$30-40$

$41-50$

$51-60$

Above 60

Sex

Male

Female

Marital Status

Single

Married

Divorced

Widow /widower

Household size

$<6$ persons

$6-10$ persons

$>10$ persons

Educational Level (years)

$<1$

$1-6$

$7-12$
Above 12

$\begin{array}{cc}08 & 6.7 \\ 30 & 25.0 \\ 52 & 43.3 \\ 12 & 10.0 \\ 18 & 15.0\end{array}$

71

59.17

49

40.83

15

12.50

75

62.50

06

5.00

$24 \quad 20.00$

$\begin{array}{lc}31 & 25.83 \\ 80 & 66.67 \\ 09 & 7.50\end{array}$

7 persons

$08 \quad 6.66$

$59 \quad 49.17$

$35 \quad 29.17$

$18 \quad 15.00$

8 years

27

22.50

35.00

42.50

18 years

$11-20$ years

51

66

55.00

54

45.00

Full time

92

28

76.67

23.33

65

54.17

45.83

45.6 years

(1)

Number of visits by Extension agents/year

$>10$ visits

55

11years

Source: author's calculation from field survey data, 2020

Table 1 further shows that rice farming in the study area was dominated by male farmers who made up 59\% of the entire respondents. The slim gap between the male and female farmers showed that the female farmers were well represented in rice enterprise in the study area. The responses of the rice farmers showed that majority $(62.5 \%)$ of the respondents were married 
and this buttresses the fact that rice farming is a good source of livelihood. The findings of this study on average age and marital status of the respondents agree with the findings of Thompson and Oparinde (2015) and Onyegbula, (2017). Further revealed is the fact that majority $(66.67 \%)$ of the respondents had household size of between 6-10 persons while $25.83 \%$ and $7.5 \%$ had less than 6 and more than 10 persons respectively. The mean household size was about 7 persons. This supports the fact that the farmers make a living from rice farming and also implies that rice farmers have tendency to engage helping hands from the household to provide family labour required for rice farming thereby providing cheaper source of farm labour.

Education brings about enlightenment, more knowledge, exposure and creates a favourable mental altitude for the acceptance of new ideas and practices. This research according to the results displayed in Table 1 identified that $49.17 \%$ of the respondents spent between $1-6$ years in school while the average number of years spent in school by the farmers was 8 years (JSS 2). This suggests that the rice farmers possess reasonable educational experience that can be useful in the study of climate change and their adaptation strategies. Also, it had been established that the educational level of farmers determine their perception of climate change to a large extent (Nwalieji and Onwubuya, 2012). The percentage of farmers without formal education is as low as $6.66 \%$ and suggests that rice farming in the study area is an enterprise dominated by farmers with some background of formal education. The number of years already spent by the rice farmers in the rice farming enterprise as shown on table 1 revealed that mean rice farming experience was 18 years, with the most $(42.50 \%)$ of the respondents already engaged in rice farming activities for a period of over 20 years. This means that the rice farmers had been farming for a fairly long period of time to enable them observe changes and variability in the pattern of climate. It further suggests that the rice farmers are comfortable with the enterprise which makes them continue with it for years.

On the mode of operation, $55 \%$ of the farmers ( 66 farmers) engaged in the enterprise on full time basis while the response of the farmers to the number of extension agents' visits in a year showed that $76.67 \%$ of the farmers had less than 10 visits from extension agents in a year while the average number of visits in a year was 8 . The importance of extension agents to farmers cannot be overemphasized because they are needed for dissemination of information which, according to Nwaiwu, et al. (2013), includes climate change adaptive and mitigation strategies that would help farmers overcome the dangers of climate change. Majority of the farmers $(54.17 \%)$ had belonged to cooperative groups for less than 10 years and this raises concern on whether the cooperative actually has something to offer. Average number of years as member of cooperative group is 11 years.

\section{Rural Rice farmers' Awareness and perception of Climate Change}

The responses of the rural rice farmers to the level of climate change awareness are presented in Table 2. On the level of awareness of climate change, majority of the rice farmers $(51.67 \%)$ were highly aware, $38.33 \%$ slightly aware while $10 \%$ were not aware of the concept. This shows that majority $(90.0 \%)$ of the farmers in the area had observed to an extent that there were significant changes in climate pattern. This is in agreement with Onyegbula, (2017) who established that rice farmers were aware of the alterations in climate parameters and a decrease in their production over the years which they adduced to climate change. 
Table 2: Distribution of the respondents according to their level of awareness of climate change

\section{Level of Awareness of Climate Change}

Highly Aware

Slightly aware

Not aware

TOTAL

\section{Frequency Percentage}

62

46

12

10.00

120
100

Table 3 shows that the rice farmers in the study area seriously perceived high intensity of sun, variation in rainfall duration and intensity, change in weather, poor yield of crops, prolonged dry season, alteration in cropping calendar as indicators of climate variability, while heavy and windy rainfall, variation in weed growth, increased incidence of drought, and insects and diseases incidence were not seen as serious perceptions of climate change. This is in affirmation of the report of Nwalieji and Onwubuya, (2012) that temperature and rainfall are the two climatic variables that influence farming the most in the study area. Naswen et al. (2016) also noted similar indicators of climate change.

Table 3: Farmers perception of climate change

\section{Perception Statement}

High intensity of sun

Variation in rainfall duration and intensity

Change in weather

Poor yield of crops

Prolonged dry season

Alteration in cropping calendar

Heavy and windy rainfall

Variation in weed growth

Increased incidence of drought

Insects and diseases incidence
Mean score

2.41
Rank

Remark $^{*}$

$$
\text { SP }
$$

SP

SP

SP

Note:* multiple responses received; Source: author's calculation from field survey data, 2020. SP means serious perception; NP means Not a Serious perception 
Influence of Socio-economic Characteristics of the Respondents on their Perception of Climate change

The results of two functional forms of multiple regression results are displayed in Table 4. The linear - linear functional form had a better result (more significant variables, and higher $\mathrm{R}^{2}$ ) and was chosen as the result for this study. It clearly revealed that sex, number of years spent in formal education, number of contacts with extension agents, farming experience, and mode of farming have significant influence on farmers' perception of climate change. The coefficient of sex is negative. This means that male farmers had less perception of what climate change is than their female counterparts. The implication of this is that the female farmers are more sensitive to climate variability than the male farmers. The number of years spent in formal education setting has a positive influence on farmers' perception of climate change. Thompson and Oparinde, (2015) reported same. The more exposed the farmers are, the more they become aware of the concept of climate change and associate numerous changes in their farm to climate variability. Farmers who had more number of contacts with extension agents are exposed to numerous ideas about climate change, and hence perceived it as a lot of things. Farming experience has a negative effect on the rural farmers' perception of climate change. The explanation to this is that farmers who had been in rice farming enterprise for a longer number of years have observed the climate variability of the area and hence tend to be stuck with an opinion of what they perceive as climate change. In essence, farmers with longer years of experience in rice farming have fixed perception of climate change because they assume they already know all about the changes in climate in the area, and hence limit the number of things they perceive as climate change. This can be attributed to over confidence. The coefficient of the mode of operation of the farmers (full time or part time) is negative. This implies that full time rice farmers in the study area perceived less variables as climate change than part time farmers possibly because they feel they have devoted enough time on the farm to enable them to be more conversant with climate change issues. The overall significance of the regression analysis is ascertained by the significance of the $\mathrm{F}$ statistic. The value of $\mathrm{R}^{2}$ which is 0.753 indicates that the socio-economic characteristics can explain up to $75 \%$ of the variation in the perception of the farmers.

Table 4: Multiple Regression result showing the effect of socio-economic characteristics of the respondents on their perception of climate change Variables

\section{Linear Linear}

Age

$-0.023(0.348)$

$-0.942$

Sex

$-0.105^{* *}(0.039)$

$0.213^{* * *}(0.000)$

6.600

$-0.067(0.195)$

Marital status
Semi log

$-0.111(0.110)$

$-1.612$

$-0.025(0.289)$

$-1.066$

$0.060^{* * * *}(0.000)$

12.052

$-0.041(0.278)$ 


\section{$-1.091$}

House hold size

$$
-0.036(0.227)
$$

$-0.002(0.682)$

\section{$-1.215$}

$-0.411$

Years as Member of cooperative group

$-0.016(0.251)$

$-0.001(0.352)$

\section{$-1.154$}

$-0.934$

Number of Contacts with extension agent

$0.316 * * *(0.007)$

$-0.002(0.606)$

\subsection{0}

$-0.517$

Farming experience

$$
-0.099^{* *}(0.013)
$$

$-0.002(0.605)$

\section{$-2.526$}

$-0.519$

Mode of farming

$-0.081^{* *}(0.031)$

$-2.183$

$2.498(0.000)$

$2.964(0.00)$

\subsection{1}

31.633

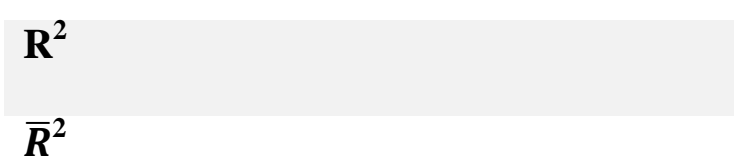

0.753

0.683

0.739

0.662

Prob> F

0.000

0.000

SE of estimate

0.616

0.820

Note: $* * \& * * *=$ significant at $5 \%$ and $1 \%$ respectively.Figures before the parentheses are the coefficients of the variables, figures in parentheses represent the p-values, while the figures in bold letters are the t-values.Source: author's calculation from field survey data, 2020

\section{Coping Strategies Adopted by the farmers}

The rice farmers employed various coping strategies to mitigate the impact of climate change in the study area. Table 5 displays the various coping strategies adopted by the rice farmers in the study area. Adjustment of the planting calendar topped the list as the most used coping strategy by the farmers in the study area. It can be seen that majority (94.17\%) of the farmers adjusted the planting calendar of their rice as a way to cope with effects of climate change. The farmers explained that they monitored the previous weather condition and adjusted accordingly in the current season. Close monitoring of weather ranked $2^{\text {nd }}$ with $88.33 \%$ of the farmers using it as a coping strategy. According to the farmers, the trend in weather change 
informed their choice of what next to do. Mixed cropping, with $81.67 \%$ of the farmers, ranked third amongst the coping strategies employed by these farmers. The farmers, in a bid to avoid the risk of loosing out entirely in a farming season, engage in planting other crops like vegetables, and maize. This agrees with the report of United Nations Framework Convention on Climate Change (UNFCCC, 2007) that local farmers engage in diverse coping strategies in a way to adapt to climate change.

Table 5: Distribution of the respondents according to the strategies adapted to cope with the impact of climate change

\section{Strategy}

Adjusting the planting calendar

Close monitoring of weather

Mixed cropping

Moderate use of agro - chemicals and fertilizers

Improvement of managerial skills

Usage of improved/resistant varieties

Increase in farm size

Usage of zero or minimum tillage

Diversification into non - farm activities

Usage of irrigation

Prayers

Construction of drainage system

Frequency*
113
106
98
91

84

78

78

73

64

48

32

18

$\begin{array}{cc}\text { Percentage } & \text { Rank } \\ 94.17 & 1^{\text {st }} \\ 88.33 & 2^{\text {nd }} \\ 81.67 & 3^{\text {rd }} \\ 75.83 & 4^{\text {th }}\end{array}$

70.00

65.00

65.00

60.83

53.00

40.00

26.67

15.00 $5^{\text {th }}$

$6^{\text {th }}$

$6^{\text {th }}$

$8^{\text {th }}$

$9^{\text {th }}$

$10^{\text {th }}$

$11^{\text {th }}$

$12^{\text {th }}$

Note *: multiple responses received because farmers employed more than one strategy. Source: author's calculation from field survey data, 2020

Figure 1 displays the number of coping strategies employed by each farmer. Less than $5 \%$ of the rice farmers used 1, 2, 3 and 11 coping strategies. Average number of coping strategies employed by the farmers is 7.36 which is approximately 7 , and $70.82 \%$ of the farmers ( 85 farmers) used up to 7 coping strategies. This shows that these rural rice farmers go all the way to ensure that they secure their crop. 


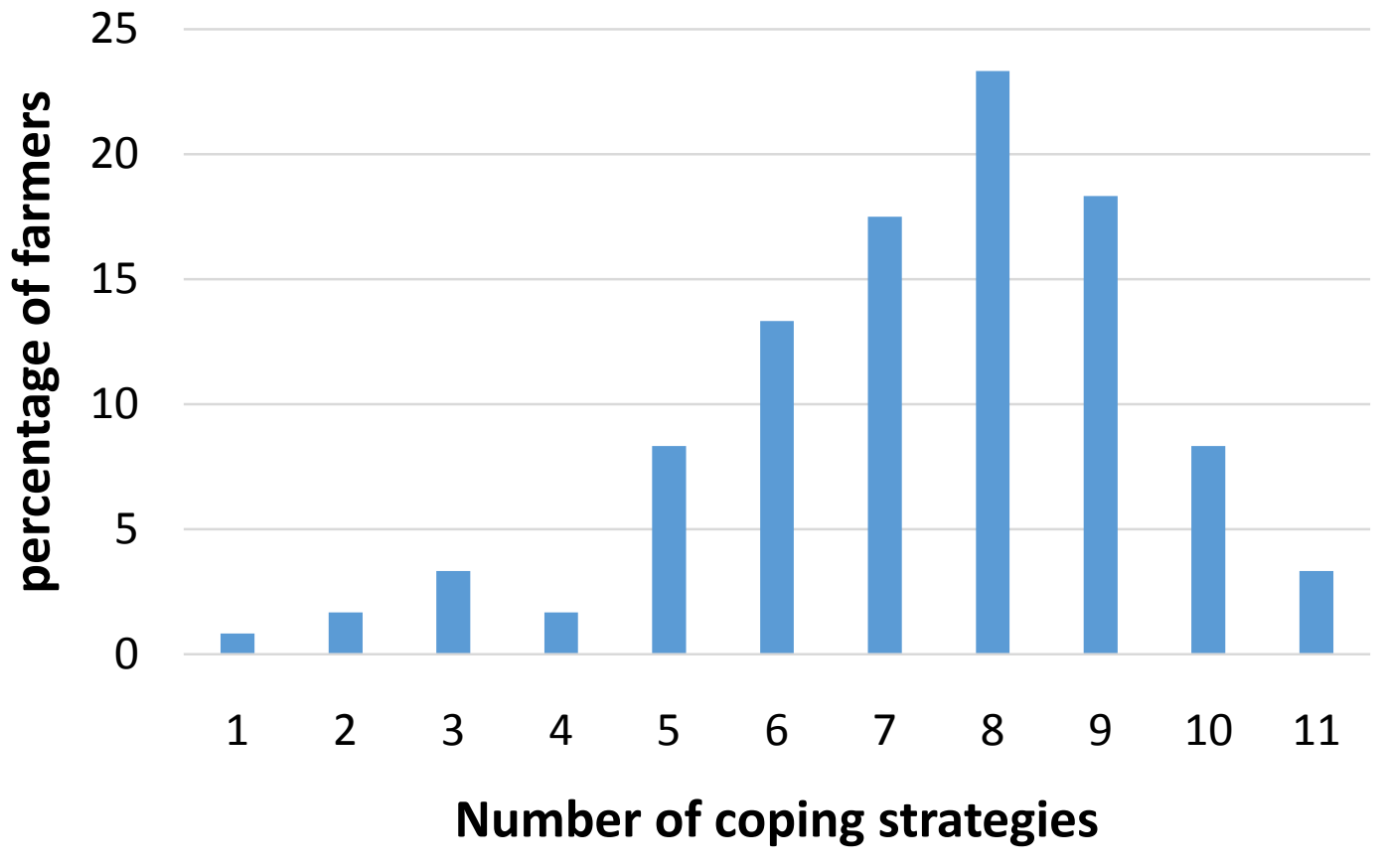

Figure 1: a bar chart showing number of coping strategies employed by the farmers.

\section{Conclusion and Recommendation}

This study examined climate change perception and coping strategies among rural rice farmers in Anambra state with the aim of ascertaining the rural rice farmers' awareness and perception of climate change, strategies employed to mitigate the impact of climate change and the effect of socio economic characteristics of the farmers on their perception of climate change.

The socio-economic characteristics of the respondents indicated that the rural rice farmers in the study area were mostly married, middle aged, full time farmers with a mean age of 45.6 years and an average household size of 7 persons. These farmers had spent an average of 8 years, 11 years and 18 years in formal education setting, farmers' cooperative groups and rice farming respectively while the extension agents visited them for an average of 8 times in a year. Rice farming in the study area was also dominated by male farmers.

Rice farmers in the study area were aware of the concept of climate change though at different levels and perceptions. Farmers' perception of climate change hinged mainly on variation in rainfall duration and intensity, high intensity of sun, change in weather, poor yield of crops, prolonged dry season, and alteration in cropping calendar. The main coping strategies employed by the rice farmers in the study area included adjusting the planting calendar, close monitoring of weather, mixed cropping, moderate use of agro - chemicals and fertilizers, improvement of managerial skills, usage of improved/resistant varieties, increase in farm size, usage of zero or minimum tillage, and diversification into non - farm activities. 
Number of years spent in school and number of contacts with extension agents influenced the rice farmers' perception of climate change positively, while Sex, farming experience and mode had negative effect on their perception of climate change.

Based on the finding, this study concludes that though the rural rice farmers in the study area are aware of the concept of climate change to an extent, a lot still needs to be done to improve their level of awareness, perception and coping strategies. The following recommendations are made:

i. There is need for greater investment in farmer education.

ii. A call for action on enlightenment through on farm education by extension agents. The extension agents should be motivated to visit the rural farmers more so as to correctly enlighten them more on the concept of climate change.

iii. On-farm education/enlightenment should be planned for the farmers to enable them have the right knowledge required, this would also put a check on the assumption that the more the number of years of experience and the more the concentration on the farm, the surer the knowledge of climate change. The rice farmers should be enlightened to understand that climate variability is dynamic and can come in various forms which can change over years.

iv. Rice farmers therefore should be advised to plant disease and improved varieties that can withstand changes in the climate.

v. Farmers should be advised to make adjustments to adapt their agriculture in response to climatic change.

vi. Regular information on current issues related to the effect of climate change on agriculture should be provided to the respondents through mass media, local communication methods, extension agents, cooperative groups etc.

vii. More female farmers should be encouraged to join the rice enterprise. 


\section{References}

Abid, M., Scheffran, J., Schneider, U. and Ashfaq, M. 2015. Farmers' perceptions of and adaptation strategies to climate change and their determinants: the case of Punjab province, Pakistan; Earth Syst. Dynam., 6, 225-243, 2015 www.earth-systdynam.net/6/225/2015/ doi:10.5194/esd-6-225-2015

Achille A. D. 2019. Farmers' perceptions of climate change and farm-level adaptation strategies: Evidence from Bassila in Benin; African Journal of Agricultural and Resource Economics 14(1) 42-55

Ayanlade, A., Radeny, M., and Akin-Onigbide, A., 2018. Climate variability/change and attitude to adaptation technologies: a pilot study among selected rural farmers' communities in Nigeria. GeoJournal83:319-331

Ayoola, S.O.,Idowu, A. A.,Opele, A. I. and Ikenweiwe, N. B. 2011. Impact of Climate Change in Nigeria. Iranica Journal of Energy \& Environment (IJEE) 2 (2) 145-152

Enibe, D. O., Cynthia, E. N., Nworji, M. J. and Okonkwo, C. A. 2019. Economic Analysis of Cocoyam Marketing in Anambra Agricultural Zone of Anambra State, Nigeria; Asian Journal of Agricultural Extension, Economics \& Sociology (AJAEES)29 (3) 1-10, 2019; Article no..46476 ISSN: 2320-7027

Enimu, S. and Onome, E., 2018. Determinants of Climate Change Adaptation Strategies among Farm Households in Delta State, Nigeria. Current investigations in Agriculture and Current Research (CIACR). November 21, 2018 ISSN: 2637-4676; DOI: 10.32474/CIACR.2018.05.000213

Falaki, A. A., Akangbe, J. A., and Ayinde, O. E. 2013. Analysis of Climate Change and Rural Farmers' Perception in North Central Nigeria; Kamla-Raj 2013 Journal of Human Ecology, 43 (2) 133-140

Idoma, K., Ikpe, E., Ejeh, L., and Mamman, M., 2017. Farmers Adaptation Strategies to the Effect of Climate Variation on Rice Production: Insight from Benue State, Nigeria.Environment and Ecology Research 5 (4) 289-301

IPCC, 2014. Climate change 2014. Synthesis report. Contribution of Working Groups I, II and III to the fifth assessment report of the Intergovernmental Panel on Climate Change [Core Writing Team: Pachauri RK \& Meyer LA (eds.)]. Geneva, Switzerland.

Naswem, A.A., Akpehe, G.A., and Awuaga, M.N., 2016. Adaptation Strategies to Climate Change among Rice Farmers in Katsina-Ala Local Government Area of Benue State, Nigeria; IOSR Journal of Agriculture and Veterinary Science (IOSR-JAVS) 9, Issue 10 Ver. I, 33-37

National Bureau of Statistics (NBS), 2013. Annual Abstract of Statistics, 2011, A publication of the National Bureau of Statistics, June

National Bureau of Statistics (NBS), 2017. Demographic Statistics Bulletin, Published by the National Bureau of Statistics, May 2018

Nwaiwu, I. U., Ohajianya, D. O., Orebiyi, J. S., Eze, C. C. and Ibekwe, U. C., 2013. Determinants of Agricultural Sustainability in Southeast Nigeria -The Climate Change Debacle; Global Journal of Agricultural Research, 1(2) 1- 13, Published by European Centre for Research Training and Development UK (www.ea-journals.org)

Nwajiuba, C. and Onyeneke, R. 2010. Effects of climate change on the agriculture of subSaharan Africa: Lessons from Southeast Rainforest Zone of Nigeria. Oxford Business \& Economics Conference Program, June 28-29, 2010.

Nwalieji, H. U. and Onwubuya, E. A. 2012. Adaptation Practices to Climate Change Among Rice Farmers in Anambra State of Nigeria; Journal of Agricultural Extension 16 (1)42 - 49http://dx.doi.org/10.4314/jae.v16i1.5 
Nzeadibe, T., Egbule, C.,Chukwuone, N. and Agu,V. 2011. Climate Change Awareness and Adaptation in the Niger Delta Region of Nigeria. African Technology Policy Studies Network WORKING PAPER SERIES | No. 57 ISBN: 978-9966-1552-6-9

Odewumi, S. G., Awoyemi, O. K., Iwara, A. I., and Ogundele, F. O. 2013. Farmer's perception on the effect of climate change and variation on urban agriculture in Ibadan Metropolis, Southwestern Nigeria. Journal of Geography and Regional Planning 6(6)209-217.

Ogbo, A., Lauretta, E., and Ukpere, W., 2013. Risk management and challenges of climate change in Nigeria. Journal of Human Ecology, 41(3)221-235.

Onubogu, O., Dipeolu, A., Momoh, S., and Olubiyi, E., (2019) Dynamic Linkages between exchange rate uncertainty and food price volatility in Lagos state, Nigeria. Invited paper presented at the 6th African Conference of Agricultural Economists, September 23-26, 2019, Abuja, Nigeria

Onyegbula C. B., 2017. Rice Farmers Perception of Effects of Climate Change on Rice Development Stages in Niger State; Journal of Agricultural Extension and Rural Development (JAERD) 9 (2) 14-19 DOI: 10.5897/JAERD2016.0838

Suleiman, I. L. 2014. An appraisal of climate change and Agriculture in Nigeria; Journal of Geography and Regional planning 7(9) 176 - 184

Thompson, O. A. and Oparinde, L. O. 2015. Farmers' Perception of Climate Change in Ondo State, Nigeria. Nigerian Journal of Agricultural Economics (NJAE). 6(1) 22-30

United Nations Framework Convention on Climate Change(UNFCCC). 2007. Climate Change: Impacts, Vulnerabilities and Adaptation in Developing Countries. Produced by the information services of the UNFCCC secretariat, Climate Change Secretariat (UNFCCC) Martin-Luther-King-Strasse 853175 Bonn, Germany. 